Psychological Aspects of Rehabilitation

Report I. Intelligence of Hemiplegic Patients after Stroke

by

Takuya KANEHISA, M. D. : The 1st Department of Internal Medicine Kagoshima University, School of Medicine

Masaaki SUGA, M. D. and Michio KOHNO, M. D. : Kirishima Branch Hospital, Kagoshima University, School of Medicine

Junichi SONODA, Phd. and Gohichi HITAKA, Phd. : Section of Clinical Psychology, Central Laboratory Kagoshima University, School of Medicine

Sunao YOSHIMUTA, M. D. : Fukuyama Hospital, Kagoshima.

Abstract

The Wechsler-Bellvue Adult Intelligence Scale was performed to thirty-four hemiplegic patients who were diagnosed as cerebrovascular lesion of internal capsule and ten healthy persons as control. Distributions of age, sex and grade of education of both groups were not statistically significant. The results were as follows :

1) The scores of hemiplegic group was lower than that of control group, especially the difference was statistically significant in total verbal scale, total performance scale, information, arithmetic, similarities, digit span and picture arrangement.

2) Mean score of total verbal scale of right hemiplegics was lower than that of left hemiplegics, but the difference was not statistically significant except that of arithmetic and digit span.

3) Comparing the differences between verbal and performance scale score of performance scale was lower than that of verbal scale and the difference was statistically significant in left hemiplegic and control group, but in right hemiplegic group the difference of them was not significant because of reduction of the score of verbal scale.

4) No definite relationship was proved between each scores and the presence of conscious disturbance or the time examined.

\title{
リハビリテーションの心理的側面
}

一一 (第 1 報) 脳卒中後片麻瘏患者の知能—

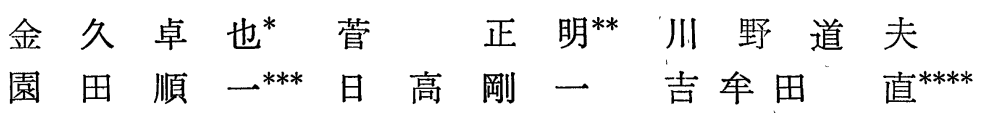

\footnotetext{
* 鹿览島大学医学部・第一内科教授

** 鹿児島大学医学部・霧島分院

$* * *$ 鹿児島大学医学部 - 中央検查部 - 心理室

**** 鹿児島・福山病院
}

はじめに

Wechsler ${ }^{1)}$ は, 知能とは個人が 合理的に行動

し, 合理的に思考し, か.つ能率的に環境を処理し 
らる綜合的能力である，と定義している。知能を 固定したものとしてではなく，このように個人の 全体としての社会的行動特性として把えようとす る, 力動的な知能観は, 人間行動の理解にとって 非常に意味のあることといえよう。

ところで, 医学的リハビリテーションの過程に

\section{第1表 調查対象}

\section{1. 調査対象}

\begin{tabular}{|c|c|c|c|c|c|}
\hline & & 性 & 実 数 & \multicolumn{2}{|c|}{ 計 } \\
\hline \multirow{2}{*}{$\begin{array}{l}\text { 片 } \\
\text { 麻 } \\
\text { 痺 }\end{array}$} & 右 & $\begin{array}{l}\text { 男 } \\
\text { 女 }\end{array}$ & $\begin{array}{r}12 \\
4\end{array}$ & 16 & \multirow[b]{2}{*}{34} \\
\hline & 左 & 男 & $\begin{array}{r}15 \\
3\end{array}$ & 18 & \\
\hline \multicolumn{2}{|c|}{ 健康者 } & $\begin{array}{l}\text { 男 } \\
\text { 女 }\end{array}$ & $\begin{array}{l}9 \\
1\end{array}$ & \multicolumn{2}{|c|}{10} \\
\hline
\end{tabular}

\section{2. 平均年齢}

\begin{tabular}{c|c|c|c}
\hline & 平 均 & S D \\
\hline \multirow{2}{*}{ 片麻 痺 } & 右 & 57.7 & 8.56 \\
& 左 & 56.8 & 8.55 \\
\hline 健 康 者 & 53.7 & 6.71
\end{tabular}

\section{3. 修学年数}

\begin{tabular}{c|c|c|c}
\hline & $\sim 8$ & $9 \sim$ \\
\hline \multirow{2}{*}{ 片麻 㽻 } & 右 & 6 & 10 \\
& 左 & 7 & 11 \\
\hline 健 康 者 & 6 & 4
\end{tabular}

おいてもっとも重要なものの 1 つは, リハビリテ ーション・プログラムを実施する際の患者の意欲 であり，それに積極的に参加し，将来の生活へ向 って現在を正しく位置づけしうる能力であること には，疑う余地はないであろう。これはすなわ ち, Wechsler の考えに従えば, 患者の知能では なかららか。リハビリテーションの過程における モーテイベーション一動機づけ一一の問題も, このような患者の知的能力の評価なしには, 到底 解決することはできないであろう。

われわれは，リハビリテーションにおける心理 的側面について種々の立場から検討を行なってい るが，ここでは脳卒中後片麻痷患者の知能につい て考察を行なってみたいと思ら。

\section{I. 調查対象}

調查対象は，障害部位が内包にあると診断され た, 脳卒中後の片麻㾝患者34名で, す心゙て右利き であり，発病までは正常な社会生活を営んでお り，知能低下や精神障害と診断されたことはな く, 中枢神経系の感染その他知能に影響を及ぼす と考えられる疾患の既往歴のあるものは，すべて 除外した。また，健康対照者として10名を選んだ。 両者の性別, 年令別, 修学年数別分布は第 1 表 に示すとおりで, 雨群の間に有意の差はない。

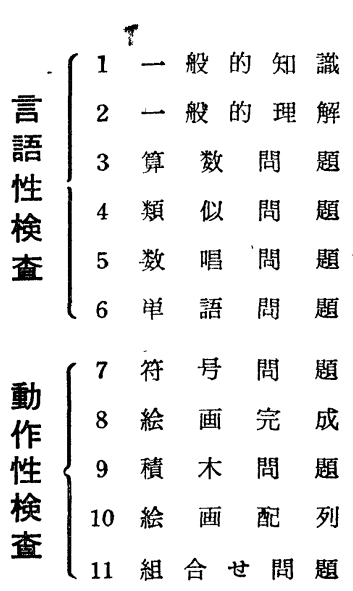

第1図片麻痺患者と健康者の下位検査比較

\section{$\begin{array}{llllllllllllllllllll}0 & 1 & 2 & 3 & 4 & 5 & 6 & 7 & 8 & 9 & 10 & 11 & 12 & 13 & 14 & 15 & 16 & 17 & 18 & 19 \\ 1 & 1 & 1 & 1 & 1 & 1 & 1 & 1 & 1 & 1 & 1 & 1 & 1 & 1 & 1 & 1 & 1 & 1 & 1 & 1\end{array}$}
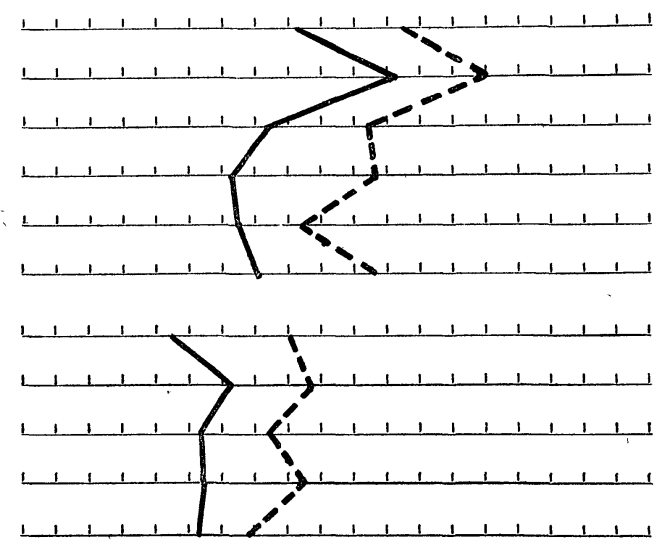

片麻痺患者

健 康 者 


\section{II. 調查方法}

臨床心理学者および心理学的訓練を受けた医師 が, 対象者全例に対して, Wechsler Adult Intelligence Scale (WAIS) の日本版 ${ }^{2)}$ 施行し, その結果について統計的処理を行なった。

\section{III. 成 績}

\section{1. 片麻痺患者亡健康者との比較}

両者の言語性及び動作性下位検查評価得点 Profile は第 1 図に示す通りであり, その各得点

第 2 表 片麻痺患者之健康者の言語性検査比較

$\mathrm{df}=42$

\begin{tabular}{|c|c|c|c|c|c|c|}
\hline & 分 類 & 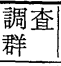 & 平 均 & S D & $\mathrm{t}$ & $\mathrm{p}$ \\
\hline 1 & 一般的知識 & 片 & $\begin{array}{l}8.15 \\
11.4\end{array}$ & $\begin{array}{l}2.90 \\
1.74\end{array}$ & 3.293 & $* *$ \\
\hline 2 & 一般的理解 & $\begin{array}{c}\text { 片 } \\
\text { 健 }\end{array}$ & $\begin{array}{l}11.38 \\
14.1\end{array}$ & $\begin{array}{l}4.29 \\
2.34\end{array}$ & 1.878 & . \\
\hline 3 & 算 数 問 題 & $\begin{array}{l}\text { 片 } \\
\text { 健 }\end{array}$ & $\begin{array}{c}7.32 \\
10.4\end{array}$ & $\begin{array}{l}2.58 \\
2.00\end{array}$ & 3.400 & $* *$ \\
\hline 4 & 類 似問題 & $\begin{array}{c}\text { 片 } \\
\text { 健 }\end{array}$ & $\begin{array}{c}6.32 \\
10.7\end{array}$ & $\begin{array}{l}4.45 \\
3.14\end{array}$ & 2.840 & $* *$ \\
\hline 5 & 数唱問題 & $\begin{array}{l}\text { 片 } \\
\text { 健 }\end{array}$ & $\begin{array}{l}6.47 \\
8.3\end{array}$ & $\begin{array}{l}2.59 \\
2.61\end{array}$ & 1.916 & \\
\hline 6 & 単語問題 & $\begin{array}{l}\text { 片 } \\
\text { 健 }\end{array}$ & $\begin{array}{c}7.09 \\
10.9\end{array}$ & $\begin{array}{l}5.26 \\
5.43\end{array}$ & 1.443 & \\
\hline & 全言 & $\begin{array}{l}\text { 片 } \\
\text { 健 }\end{array}$ & $\begin{array}{l}46.74 \\
65.8\end{array}$ & $\begin{array}{l}18.01 \\
13.01\end{array}$ & 3.044 & $* *$ \\
\hline
\end{tabular}

の平均值，標準偏差は第 2 および第 3 表のように なる。すなわち, 評価得点平均および標準偏差は いずれの下位検查においても，片麻痺患者群は健 康者群より低值を示しており，このうち言語性検 查における一般的知識, 算数問題, 類似問題, な らびに動作性検査における符合問題, 絵画配列は $1 \%$ の危険率で, また動作性検查中の絵画完成は $5 \%$ 危険率で，両者の間に有意の差が見られ た。

全言語性, 全動作性評価得点合計は, いずれも 片麻愺患者において低く，1\%色険率で有意であ った。また, 全検查評価得点合計は, 片麻瘏患者 群で平均 73.74 , 標準偏差 26.53 , 健康者群で平均

第 3 表 片麻疩患者と健康者の動作性検査の比較

\begin{tabular}{|c|c|c|c|c|c|c|}
\hline & 分 類 & $\mid$ & 平均 & SD & $t$ & $\mathrm{p}$ \\
\hline 7 & 符号問題 & $\begin{array}{l}\text { 片 } \\
\text { 健 }\end{array}$ & $\begin{array}{l}4.47 \\
8.0\end{array}$ & $\begin{array}{l}2.09 \\
1.55\end{array}$ & 4.841 & $* *$ \\
\hline 8 & 絵画完成 & 片 & $\begin{array}{l}6.26 \\
8.7\end{array}$ & $\begin{array}{l}2.55 \\
2.69\end{array}$ & 2.566 & $*$ \\
\hline 9 & 積木問題 & $\begin{array}{l}\text { 片 } \\
\text { 健 }\end{array}$ & $\begin{array}{l}5.47 \\
7.5\end{array}$ & $\begin{array}{l}2.90 \\
2.38\end{array}$ & 1.976 & \\
\hline 10 & 絵 画 配 列 & $\begin{array}{c}\text { 片 } \\
\text { 健 }\end{array}$ & $\begin{array}{l}5.62 \\
8.4\end{array}$ & $\begin{array}{l}2.56 \\
2.42\end{array}$ & 2.986 & $* *$ \\
\hline 11 & 組合せ問題 & 片 & $\begin{array}{l}5.18 \\
6.9\end{array}$ & $\begin{array}{l}3.17 \\
2.27\end{array}$ & 1.563 & \\
\hline & 全 動 & $\begin{array}{l}\text { 片 } \\
\text { 健 }\end{array}$ & $\begin{array}{l}27.00 \\
395 .\end{array}$ & $\begin{array}{r}11.77 \\
8.58\end{array}$ & 3.051 & $* *$ \\
\hline
\end{tabular}

$* * \mathrm{P}<0.01 \quad * 0.01<\mathrm{P}<0.05$

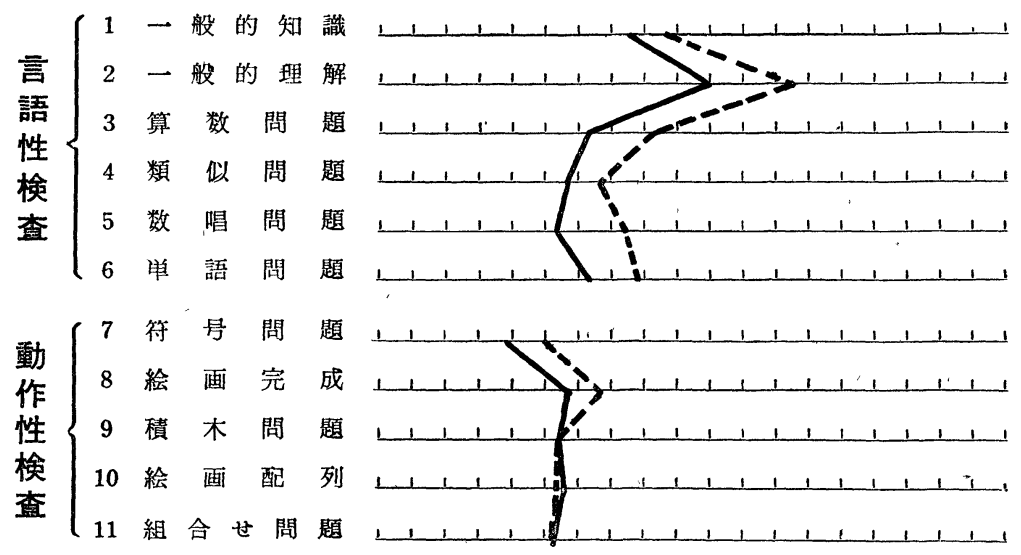


第 4 表 右及び左片麻瘏患者の言語性比較

$\mathrm{df}=32$

\begin{tabular}{|c|c|c|c|c|c|c|}
\hline & 分 類 & \begin{tabular}{|l} 
|麻痺 \\
側
\end{tabular} & 平 均 & S D & $t$ & $\mathrm{p}$ \\
\hline 1 & 一般的知識 & $\begin{array}{l}\text { 右 } \\
\text { 左 }\end{array}$ & $\begin{array}{l}7.56 \\
8.67\end{array}$ & $\begin{array}{l}2.94 \\
3.09\end{array}$ & 1.039 & \multirow{6}{*}{ * } \\
\hline 2 & 一般的理解 & $\begin{array}{l}\text { 右 } \\
\text { 左 }\end{array}$ & $\begin{array}{l}10.00 \\
12.61\end{array}$ & $\begin{array}{l}4.23 \\
4.55\end{array}$ & 1.114 & \\
\hline 3 & 算 数 問 題 & $\begin{array}{l}\text { 右 } \\
\text { 左 }\end{array}$ & $\begin{array}{l}6.31 \\
8.22\end{array}$ & $\begin{array}{l}2.05 \\
2.68\end{array}$ & 2.243 & \\
\hline 4 & 類似問題 & $\begin{array}{l}\text { 右 } \\
\text { 左 }\end{array}$ & $\begin{array}{l}5.75 \\
6.83\end{array}$ & $\begin{array}{l}4.61 \\
4.73\end{array}$ & 0.652 & \\
\hline 5 & 数唱問題 & $\begin{array}{l}\text { 右 } \\
\text { 左 }\end{array}$ & $\begin{array}{l}5.44 \\
7.39\end{array}$ & $\begin{array}{l}2.27 \\
2.75\end{array}$ & 2.193 & \\
\hline 6 & 単語問題 & $\begin{array}{l}\text { 右 } \\
\text { 左 }\end{array}$ & $\begin{array}{l}6.25 \\
7.83\end{array}$ & $\begin{array}{l}5.42 \\
5.09\end{array}$ & 0.850 & \\
\hline & 全言語 性 & $\begin{array}{l}\text { 右 } \\
\text { 左 }\end{array}$ & $\begin{array}{l}41.31 \\
51.56\end{array}$ & $\begin{array}{l}16.85 \\
17.62\end{array}$ & 1.677 & \\
\hline
\end{tabular}

第 6 表 言語性と動作性の平均評価点

\begin{tabular}{|c|c|c|c|c|c|}
\hline & & $\begin{array}{l}\text { 平均 } \\
\text { 評価点 }\end{array}$ & S D & $t$ & $\mathrm{p}$ \\
\hline 右片麻痺 & $\begin{array}{l}\text { 言語性 } \\
\text { 動作性 }\end{array}$ & $\begin{array}{l}6.89 \\
5.23\end{array}$ & $\begin{array}{l}2.81 \\
2.30\end{array}$ & 1.7705 & \\
\hline 左片麻痺 & $\begin{array}{l}\text { 言語性 } \\
\text { 動作性 }\end{array}$ & $\begin{array}{l}8.59 \\
5.56\end{array}$ & $\begin{array}{l}2.94 \\
2.36\end{array}$ & 3.2973 & $* *$ \\
\hline 全片麻痺 & $\begin{array}{l}\text { 言語性 } \\
\text { 動作性 }\end{array}$ & $\begin{array}{l}7.79 \\
5.40\end{array}$ & $\begin{array}{l}2.98 \\
2.35\end{array}$ & 3.6177 & $* *$ \\
\hline 健 康 者 & $\begin{array}{l}\text { 言語性 } \\
\text { 動作性 }\end{array}$ & $\begin{array}{r}10.97 \\
7.90\end{array}$ & $\begin{array}{l}2.17 \\
1.72\end{array}$ & 3.326 & $* *$ \\
\hline
\end{tabular}

105. 30 標準偏差 18.67 であり, $\mathrm{t}=3.434$ で両者の 間に $1 \%$ の危険率で有意の差が見られた。

以上の評価得点を知能指数 $(I \mathrm{Q})$ に換算して みると, 片麻㽻患者群では, 言語性 I Q91.6, 動 作性 I Q 79.7, 全検査 I Q 85.7, 健康者群では 言語性 I Q 111.3, 動作性 I Q 94.6, 全検査 I Q 103.2 となった。

\section{2. 左および右片麻痖患者の比較}

両者の言語性および動作性下位検查評価得点 Profile を示すと, 第 2 図のとおりで, 各評価得 点平均および標準偏差は第 4 およよ゙第 5 表のよう になる。言語性検査では, 各下位検查評価得点平 均はいずれも, 右麻痺患者群は左片麻疩患者群に 比して低く，算数問題および数唱問題では $5 \%$ の 危険率で有意の差が見られた。動作検査では, 符 合問題及び絵画完成において軽度の得点差を認め たほかほとんど差異はなく, いずれも推計学的に
第 5 表 右及び左片麻痺患者の動作性検査

\begin{tabular}{|c|c|c|c|c|c|}
\hline & 分 類 & \begin{tabular}{|l|} 
麻痹 \\
側
\end{tabular} & 平 均 & S D & $\mathrm{t}$ \\
\hline 7 & 符号問題 & $\begin{array}{l}\text { 右 } \\
\text { 左 }\end{array}$ & $\begin{array}{l}3.88 \\
5.00\end{array}$ & $\begin{array}{l}1.76 \\
2.47\end{array}$ & 1.461 \\
\hline 8 & 絵画完成 & $\begin{array}{l}\text { 右 } \\
\text { 左 }\end{array}$ & $\begin{array}{l}5.81 \\
6.07\end{array}$ & $\begin{array}{l}2.46 \\
2.54\end{array}$ & 0.970 \\
\hline 9 & 積木問題 & $\begin{array}{l}\text { 右 } \\
\text { 左 }\end{array}$ & $\begin{array}{l}5.50 \\
5.44\end{array}$ & $\begin{array}{l}2.94 \\
2.53\end{array}$ & 0.062 \\
\hline 10 & 絵 画 配 列 & $\begin{array}{l}\text { 右 } \\
\text { 左 }\end{array}$ & $\begin{array}{r}5.69 \\
5.56\end{array}$ & $\begin{array}{l}2.62 \\
2.50\end{array}$ & 0.144 \\
\hline 11 & 組合せ問題 & $\begin{array}{l}\text { 右 } \\
\text { 左 }\end{array}$ & $\begin{array}{l}5.25 \\
5.11\end{array}$ & $\begin{array}{l}3.35 \\
3.00\end{array}$ & 0.125 \\
\hline & 全 動 仡 & $\begin{array}{l}\text { 右 } \\
\text { 左 }\end{array}$ & $\begin{array}{l}26.13 \\
27.78\end{array}$ & $\begin{array}{l}11.49 \\
11.95\end{array}$ & 0.253 \\
\hline
\end{tabular}

有意の差は無かった。

全言語性，全動作性評価得点合計の各々におい ても，両群間に有意の差はなく，全検査評価得点 平均は, 右片麻痺患者群で平均 67.44, 標準偏差 24.48 , 左片麻㾇患者で平均 79.33, 標準偏差 27. 04 であり, $t=1.292$ で両者の間に有意の差はな かった。

\section{3. 言語性と動作性の比較}

左および右片麻瘏患者群，健康者群における言 語性並びに動作性評価得点を比較すると第 6 表の ようになる。表中の平均評価点は，言語性抢よび 動作性の各評価合計点を, それぞれの下位検查項 目の数で徐した数字である。いずれの群において も，動作性検査評価得点平均は言語性検査のそれ に比して低く，健康者群および左片麻痷患者群で は $1 \%$ の危険率で有意の差が認められたが，右片 麻瘏患者群の言語性評価得点は左片麻瘏患者に比 して低く，言語性と動作性との間に著明な差はな かった。

\section{4. 発病時意識障害の有無と評価得点}

片麻瘏患者34名中, 発病時の意識障害に関する 記載の明らかな26名について検討した。意識障害 が 12 時間以上持続したものを 意識障害 (十) と し，持続が 12 時間以下か，全く意識障害のなかっ たものを意識障害 (一) とした。前者は11名, 後 者は15名であるが，第7表に示したように，両者 の各平均評価得点に有意の差はなかった。

\section{5. 発病加らの期間と評価得点}

発病からの期間と，各評価得点平均との関係を みると, 第 8 表のようになる。即ち, 発病 1 年以 
第 7 表 意識障害の有無と評価点

\begin{tabular}{|c|c|c|c|c|c|c|}
\hline & $\begin{array}{l}\text { 意識 } \\
\text { 障害 }\end{array}$ & 人数 & $\begin{array}{l}\text { 平 均 } \\
\text { 評価点 }\end{array}$ & S D & $\mathrm{t}$ & $\mathrm{p}$ \\
\hline 言語性 & & $\begin{array}{l}11 \\
15\end{array}$ & $\begin{array}{l}48.09 \\
50.60\end{array}$ & $\begin{array}{l}19.64 \\
17.17\end{array}$ & 0.3328 & 0.8 \\
\hline 動作性 & & $\begin{array}{l}11 \\
15\end{array}$ & $\begin{array}{l}31.09 \\
24.53\end{array}$ & $\begin{array}{l}31.09 \\
24.53\end{array}$ & 1.2824 & 0.3 \\
\hline 全検査 & $( \pm)$ & $\begin{array}{l}11 \\
15\end{array}$ & $\begin{array}{l}79.18 \\
75.13\end{array}$ & $\begin{array}{l}32.00 \\
24.28\end{array}$ & 0.3525 & 0.8 \\
\hline
\end{tabular}

内のものと 1 年以上経過したものとの間に, 特に 差異を見出すことはできなかった。

\section{IV. 考 按}

これまでにえられた結果についてまずあげられ ることは，片麻㿁患者群と健康者のいずれにおい ても，言語性に比し；動作性の低いことである。 年令による WAIS の下位検査の得点減衰につい ては, Rabin $^{3)}, \mathrm{Fox}^{4) 5)}, \mathrm{Cohen}^{6)}$ などの研究が あり，Cohen は困子分析法を用いて得点を左右 する主要因子として，言語理解，知覚的統合能力 及び記憶の3つを挙げ，Fox は加令による得点 の減衰は，とくに積木問題，絵画配列及び符合問 題の下位検査において著明であり，加令による言 語性の低下は少いと述べている。WAIS 米国原 版における統計においても，日本語版標淮化にお いても, 動作性検查得点の年令30歳以後の減衰勾 配は，言語性検査得点のそれより大となって㧍 り，これらの点よりわれわれの例における動作性 検査得点の低いことは，年令因子の関与によるも のと考えてよいであろう。

脳器質的疾患と知能について Kloeve ${ }^{7)}$ は, W'AIS と脳波異常との間に関係があるとし， $\mathrm{Ullman}^{8)}$ は, 脳卒中後片麻瘏患者の行動変化に ついて記載し，知能因子の重要性をあげている が, 詳細な研究の記載は少ないようである。Wechsler は脳器質的疾患においては, 数唱問題, 符合問題, 類似問題, 算数問題の得点が低くなる といっている。われわれのえた結果では, 言語性 のらち一般的知識, 算数問題, 類似問題の $3 つ の$ 下位検査が片麻痺患者群で低くなっている。 Rapaport ${ }^{10)}$ は語彙に関する検查は小児期の教育 による影響が大きく, 成人して後の生活経験に影 響されることは少ないと述べているが，一般的知
第 8 表 発病からの期間と評価点

\begin{tabular}{l|c|c|c|c|c|c}
\hline & & 人数 & $\begin{array}{c}\text { 平均 } \\
\text { 評価点 }\end{array}$ & S D & $\mathrm{t}$ & $\mathrm{p}$ \\
\hline 言語性 & 1 年以下 & 18 & 45.67 & 16.96 & 0.3549 & 0.8 \\
& 1 年以上 & 16 & 47.94 & 19.06 & & \\
動作性 & 1 年以下 & 18 & 26.56 & 11.00 & 0.2257 & 0.9 \\
& 1 年以上 & 16 & 27.50 & 12.49 & & \\
全検査 & 1 年以上 & 18 & 72.22 & 22.24 & 0.3442 & 0.9 \\
& 1 年以下 & 16 & 75.44 & 30.44 & &
\end{tabular}

識のような語彙問題が片麻瘏患者群において低い ことは, 修学年数に健康者群との間に大差のない ことから，片麻疩患者群には全般的な精神機能の 退行が同一年令者に比していちじるしいことや， あるいは社会生活から隔離されているために知的 興味の減退を来していることなどが原因としてあ げられよう。健康者群 の数唱問題得点 平均が 低 く, このため片麻愺患者群との間に差がなかっ たが，これをただちに意味づけることはできな い。動作性検査では, 片麻痺患者群において, と くに符合問題, 絵画配列の得点が低かった。 Wechsler によると, 前者注新しい学習課題に対 する柔軟性を示すものであり，後者は全体を把握 する能力を現わすものであると述べている。前者 における利き手障害の影響は否定できないが，片 麻痷者群ではこれらの，いわば環境に適応し積極 的に働きかける能力が低下していると考えられる が，WAIS 得点が発病よりの期間と余り関係し ていないことからして，そのもっとも大きな原因 は, 脳の退行性変化に求めることができるのでは なかろらか。一方, 絵画完成, 積木問題, 組合せ 問題のような, 視覚運動機構の測定に関与すると いわれている下位検查得点が，片麻盘患者群にお いてとくに著明な差を示さなかった点は, 非常に 興味深いことであり，今後精しい検討を要するこ とである。

次に, 大脳半球の障害側と知能との関係につい

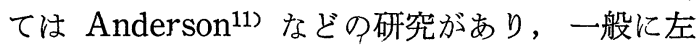
半球障害においては言語性検査の障害があり，右 半球障害では空間的あるいは空間的一時間的関係 に関する検査において低下が著明であるといわれ ている。Heilbrun ${ }^{12)}$ は，種々の大脳半球に障害 のある患者について WAIS を行ない, 左半球障 害患者においてとくに言語機能の低下を認め, 
$\operatorname{Reitan}^{13)}$ も同じく左半球障害者における言語性 検查の評価得点の低下を強調している。われわれ の場合, 左・右片麻舫患者において, 言語性と動 作性にとくに差異が見られなかった点は Heilbrun や Reitan の成績と異なるが，これは Rei$\tan$ らの対象の中には皮質障害例, 失語症例など が含まれており，われわれの例は内包障害に限定 し, 失語症例を除外しているなど, 対象群の選び 方の差異によるものと思われる。しかし，われわ れの場合も, 言語性と動作性の平均評価点を比較 してみると, 右片麻痺患者群すなわち左半球に障 害のある群において，言語性検査評価点が低くな っていることは，これらの患者においても潜在性 の言語性機能低下の存在を推定させるものであろ 亏。

\section{むすび}

以上, 平均年令57歳の脳卒中後片麻疸患者34名 の WAIS 検查所見について述心，同一年令層の 健康人との比較, 左および右半球障害と知能の問 題などについて検討を行なった。

(本論交の要旨は，第 1 回日本リハビリテーション医 学会及び第 6 回日本神経学会で発表した。)

\section{参考文献}

1) Wechsler, D. : The mesurement of adult in- telligence, The Williams \& Wilkins Co., Baltimore, 1963. 2) 坚玉, 品川, 印東: WAIS 成 人知能診断検查法, 日本文化科学社, 東京, 1963. 3) Rabin, A.I. : Psychometric trends in senility and psychosis of the senium, J. Gen. Psychol., 32, 149-162, $1945 . \quad$ 4) Fox, C. \& Birren, J. E. : Some factors affecting vocabulary size in later maturity : age, education and length of institutionalization, J. Geront., 4, 19-26, 1949. 5) Fox, C. \& Birren, J. E. : The differential decline of subtest scores of the WechslerBellevue Intelligence Scale in 60-69-year-old individuals, J. Gen. Psychol., 77, 313-317, 1950. 6) Cohen, J. : The factorial structure of the WAIS between early adulthood and old age, J. Consult Psychol., 21, 183-190, 1957. 7) Klove, H. \& White, P. T. : The relationship of degree of electroencephalographic abnormality to the distribution of Wechsler-Bellvue scores, Neurology, 13, 423-430, 1963. 8) Ullman, M. : Behavioral changes in patients following strokes, Charles C Thomas, Springfield, 1962. 9) Wechsler, D. : 1) に同じ. 10) Rapaport, D., Gull, N. \& Schafer, R. : Diagnostic Psychological Testing, Vol I, Year Book Pub. Inc., Chicago, 1945. 11) Anderson, A. L. : The effect of laterality localization of focal brain lesions on the Wechsler-Bellvue subtests, J. clin. Psychol., 7, 149-153, 1951. 12) Heilbrun, A. B. : Psychological test performance as a function of lateral localization of cerebral lesion, J Comp. \& Physiol. Psychol., 49, 10-14. 1956. 13) Reitan, R. M. : Certain differential effects of left and right cerebral lesions in human adults, J. Comp. \& Physiol. Psychol., 48, 474-477, 1955.

整形外科学 全 2 巻

編集／岩原 寅猪・片山，良亮

上巻 B 5 ・頁 1004 ・図 561 ・写真 $419 \cdot ¥ 8,500$ ・ 200

下巻 B 5 ・頁 $1000 \cdot$ 図・写真 $850 \cdot ¥ 9,500 \cdot$ 干 200

骨折・脱帠・捻 挫

編集/恩地 裕・上野良三・内海庄三郎

B 5 • 頁 236 •図 150 • 写真 114 ・原色 1 ・ 3,000 • 干 120 